DOI: $10.22616 /$ REEP.2020.001

\title{
Multimedia technologies in teaching a foreign language
}

\author{
Akzhan Abdykhalykova ${ }^{1}$ Dr.paed.; Larissa Turusheva ${ }^{2}$ Dr.paed. \\ Zhanna Beysembayeva ${ }^{3}$ Dr.philol.; Gulzhannat Dukembay ${ }^{4}$ Dr.philol. \\ L.N. Gumilyov Eurasian National University, Kazakhstan ${ }^{1,3,4}$ \\ EKA University of Applied Sciences, Latvia ${ }^{2}$ \\ akzhan80@mail.ru'; larisa.turuseva@eka.edu.lv²; zhannabei@mail.ru³; dukenbai_gn@mail.ru
}

\begin{abstract}
At the present stage of development of education, Kazakhstan higher school faces the task of improving the quality of training, which with the introduction of new state educational standards (both for undergraduate and graduate) is associated with the prospect of implementing a technological approach to learning, science-based new pedagogical and information technologies. In this regard, the aim of the research is to highlight the problem of finding the optimal didactic capabilities of modern information technologies used for improving the system of training specialists in the field of foreign languages teaching. The article reveals the main components of the system of modern technologies use in foreign languages teaching at Theory and Practice of Foreign Languages Department of L.N. Gumilyov Eurasian National University. The article presents training and monitoring online programmes, their approbation in real conditions of pedagogical activity, which proves the effectiveness of using the modern technologies in the training of foreign and second language students. The authors summarized the relevant literature and results of the research and teaching experience. The electronic educational materials, recommendations developed by the authors can be used in teaching a foreign language and can serve as a basis for the development of information, communication and instrumental provision in other subjects. The need for further research is to create online platforms, multimedia and testing programmes, to develop variants of using modern technologies in foreign language teaching.
\end{abstract}

Keywords: foreign language teaching, multimedia technology, online platform, university education.

\section{Introduction}

The information technology age, which has taken a significant place in the educational process, begins to take multimedia learning tools that occupy a worthy place in the University.

At the present stage of development of education, Kazakhstan higher school faces the task of improving the quality of training, which with the introduction of new state educational standards (both for undergraduate and graduate) is associated with the prospect of implementing a technological approach to learning, science-based new pedagogical and information technologies.

Implementation of the technological approach in the preparation of the future teacher of English is hampered by the following contradictions:

- between the rapidly growing level of development of Kazakhstan's information society and the ability of the higher education system to meet the growing requirements;

- between the need to improve the professional training of future teachers of foreign languages on the basis of technological approach and the weak readiness of University teachers;

- between versatile research and development in the science of theoretical bases of information technologies and insufficient attention to their implementation in the field of professional training of the expert in the field of teaching of foreign languages;

- between the broad didactic possibilities of information and communication technologies (ICT) and the low level of their use in the practice of education at the University.

The following questions arise from the identified contradictions, the first, whether the existing system of professional training of future teachers of foreign languages is capable to provide formation of professional competences, which meet new requirements and the second what should the training of future specialists in the field of foreign languages at the University be, so that they can continue to work competently with information and effectively use, as well as be able to develop multimedia technologies in their activities? 
These issues together defined the problem of research, which is to improve the system of teaching disciplines on the methodology of teaching foreign languages at the University through ITC and their instrumental support. Referring to the analysis of the initial facts, contradictions and the problem, we highlight the following main idea of our research: the ability to navigate in the ever-increasing volume of information, to use it correctly for various purposes, to use modern means of communication that should become essential components of the modern content of pedagogical education, and a computer $-\mathrm{a}$ tool for managing the educational process.

According A.P. Gilakjani (2017), the use of technology helps learners to get involved and learn based on their interests. It has been extensively accepted for teaching English in the modern world. Technology satisfies both visual and auditory senses of the learners (Shyamlee, Phil, 2012). M. Chirwa (2018) said that several studies in the whole world have shown that the appropriate use of multimedia technology in educational context would provide quite a lot of benefits.

A. Frigaard (2002) and M. Timuçin (2006) confirmed that technology increases the development of teaching methods and learners' knowledge. Y. Lam and G. Lawrence (2002) also expressed that technology helps learners to regulate their own learning process and have access to any information that their teachers cannot provide. A.P. Gilakjani and L. Lai-Mei (2012) elaborated that the unique opportunities technologies provide have brought about new tools, approaches, and strategies in the teaching and learning of language skills. Technologies are increasingly widespread, impacting many aspects of our social and work lives, and many of our leisure activities. Many researchers stated that technology could be used as an instructional tool in teaching and learning skills. B.C. Bruce and J.A. Levin (2003) expressed that technology can be useful in the classroom by helping communication, making teaching products, and assisting learners' self-expression. According to A.P. Gilakjani (2017), when we talk about instruction, education, or training issues we have to consider the important role of technology. The researchers continued that the application of technologies in education opens a new area of knowledge and provides a tool that has a great potential to change the existing teaching methods.

The use of a computer in teaching a foreign language is not limited to classroom activities. Various researchers offer options for the use of Internet technologies in the classroom and in extracurricular work of students. For example, the use of ICT in teaching foreign languages is considered in the works of Russian and Kazakh scientists E.V. Artykbayeva (2014), G.K. Nurgalieva (2002), G.K. Kenzhebayev, T.T. Dalayeva, (2014), G.V. Rogova, F.M. Rabinovich, T.E. Sakharova (1991).

A promising direction in the study is the use of Internet technologies, various aspects of which are devoted to many publications. In recent years, a lot of attention of teachers is attracted by the mass open online courses as a new form of online education, since they allow anyone to learn practical training, regardless of time and location.

The question of formation of the content of foreign language teaching methods in universities received plenty attention from scientists. The scope of application of ICT in teaching foreign languages, including such scientists as S.S. Kunanbayeva (2000), D. Nurmukhanova, Zh. Sagyndykova, I. Līce, J. Pāvulēns (Nurmukhanova et al., 2014) made a great contribution to teaching foreign languages in Kazakhstan.

However, in our opinion, to date, the impact of online learning on the quality of education has been insufficiently studied. We also try to work with students online, but now we have not received enough results to mention this direction in the article. The analysis of literature and educational practice has allowed coming to a conclusion that in the conditions of fast growth of the volume of information the computer can become the tool of management of the educational process. New information technologies do not displace the traditional system of education and innovative pedagogical technologies, but complement and strengthen each other. This integration requires further research to improve the quality of training of the future teacher of a foreign language.

The aim of the research is to highlight the problem of finding the optimal didactic capabilities of modern information technologies used for improving the system of training specialists in the field of foreign languages teaching. 


\section{Methodology}

In the process of research, the following methods were used: theoretical (analysis of pedagogical, psychological, methodical literature, normative and programme - methodical documentation, Internet resources; generalization; forecasting, design and modelling), a diagnostic questionnaire on Google forms, empirical (pedagogical observation), and methods of graphic representation of the results.

The experimental base of the research was L.N. Gumilyov Eurasian National University, Philology Faculty, Theory and Practice of Foreign Languages Department, Specialty "Foreign languages: two foreign languages".

The study of the problem was carried out in two stages:

- at the first stage, an information system of foreign language teaching was developed, a set of components of this system was identified and justified for the effective training of the future teacher of foreign languages;

- at the second stage, experimental work was carried out, analysed, tested and refined insights obtained in the course of the pedagogical experiment, were summarized and the obtained results reported.

Participants. The study was conducted in two groups. Both groups had 25 people from 20-35 years old, they were equivalent in the direction of training, academic performance and teaching programme. In the first group (experimental) multimedia technologies were used in the educational process, and in the second group (control) the educational process was organized by the traditional method.

Experimental procedure. The study was conducted during one semester. After the final testing of the level of performance, the results of the study were processed and analysed. When processing the results, a test was used to check the differences between the control and experimental groups.

At the 1st stage, a survey was conducted, and 30 English language teachers took part in it. The questionnaire included the following questions:

1. What pedagogical technologies do you primarily use in your lessons?

2. Does the use of this technology make it possible to fully implement the tasks of the lesson?

3. What is the leading motive for students attending your English lessons?

4. What tools should be used to strengthen interest in the English language.

5. Do you have computer skills?

6. Is your office equipped with computer equipment?

7. How often do you use a computer in class?

8. What computer technologies are most accessible and easy to use for you?

The purpose of the second stage of the experiment was to identify students' use of multimedia technologies in the educational process, and 80 students took part in it. The questionnaire included several questions, which helped understand the use of multimedia technology effectiveness in the educational process. Thus, we were interested in the students' vision on implementation of multimedia technologies at the lesson, their practical skills in the use of them and the accessibility of computer technologies for them.

\section{Results and Discussion}

The analysis of the responses of the surveyed teachers (1st stage) gave the following results: on the first question, the majority ( $40 \%$ ) answered that they continue to use traditional methods in lessons, $23 \%$ use traditional and information technologies, $24 \%$ implement project technologies, group and pair work, and only $13 \%$ of teachers use game technologies (Figure 1). 


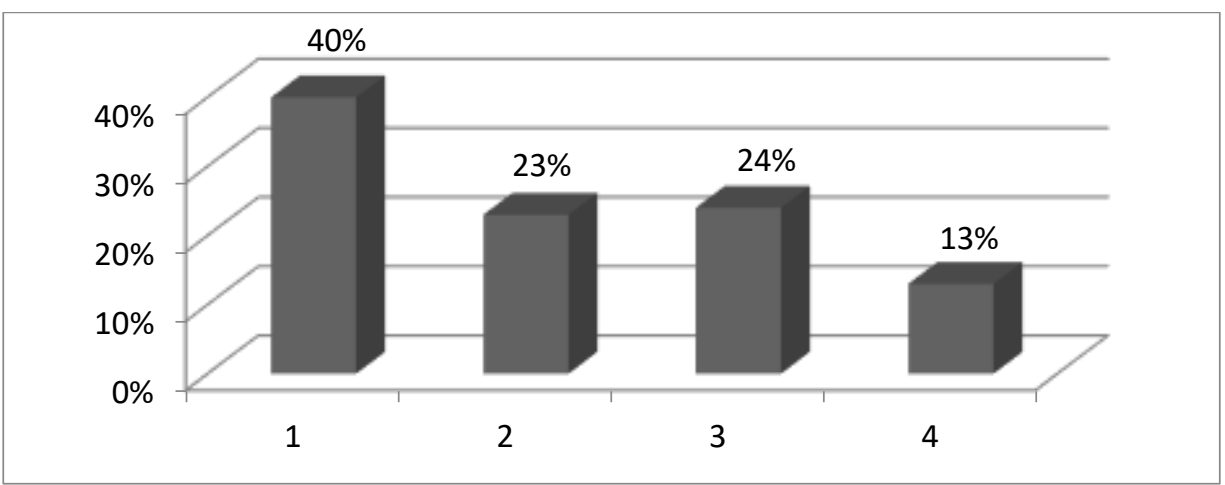

Figure 1. The analysis of the responses of the surveyed teachers.

( 1 - indicator of users of traditional methods, 2 - indicator of users of traditional and information technologies, 3 - indicator of users of project technologies, group and pair work, 4 - indicator of users of game technologies)

The comparative analysis of the responses of the surveyed teachers and students gave the following results:

- by the first question on the use of different methods at the lesson, the answers of students completely coincide with the answers of teachers. Thus, $40 \%$ said that the teachers continue to use traditional methods in the lessons, and $60 \%$ use both traditional and information technologies.

- by the second question (whether the use of technology makes it possible to fully implement the tasks of the lesson), as a result of the analysis of the teachers' answers, it was concluded that the use of conventional pedagogical technologies does not always make it possible to fully implement the tasks set in the lesson. The use of new technologies does not always implement the objectives of the lesson either. This is due to the technical side of the learning process, computer illiteracy and inability to work in groups and pairs.

- by the third question (on leading motives of students to attend particular lessons), all teachers, based on their observations, first believe that children come to the lesson to get an assessment. $47 \%$ are aware of the need for knowledge of English in their future professional activities, $24 \%$ - the need to learn a foreign language to further expand the circle of communication, $19 \%$ come to an English lesson in search of new knowledge and only $10 \%$ pursue motives caused by fear of the school management or their parents;

- by the fourth question on the tools to be used, $71 \%$ of teachers and students noted that the use of information technologies in the classroom (training presentations, educational films, Internet resources, electronic textbooks) increases interest in learning English, while the remaining $29 \%$ of teachers believe that it is possible to use new technologies in the classroom for this purpose (group and pair work, projects.);

- the following four questions (No 5 - 8) were selected in order to find out the level of computer literacy of teachers, whether all school classrooms in English are equipped with computer equipment and what difficulties arise when implementing information technologies in the educational process. As a result of counting the responses, the following ratio was revealed. $50 \%$ of teachers do not have enough computer skills to be able to regularly use information technology in the learning process. And it is mainly the teachers of the older generation. $20 \%$ of teachers experience difficulties in using computer technology due to the lack of equipped classrooms, and the remaining $30 \%$ successfully implement computer technology in the educational process.

At the first stage of existing methodological approaches to teaching a foreign language, the aim was to develop students' ability to understand the process of developing online technologies. Although the needs of the analysis have become an important stage in the development of a foreign language for professional purposes, it has mainly provided information on what to teach, leaving unanswered the question of how to teach. Systematization of previous experience has led to the fact that the students' needs were in the centre of attention of developers of foreign language programs for professional purposes. This approach was called personality-oriented (learning-centred approach), in which the 
centre is the personality of the student and his cognitive activity, and the students' needs are the basis for the construction of the course.

Information technologies open up new opportunities for the future teacher of foreign languages, form a new way of thinking and action lay the foundations of new ethics and culture of understanding of the world. The basis of information technology of foreign language learning is computer training, for the successful implementation of which (in addition to the computer as the main technical means) requires special didactic tools and thoughtful methods of working with them.

At the second stage, students developed multimedia products for teaching and learning English. We carried out this work in the following areas:

- creation of electronic learning platforms, blogs that can be used as a means of visibility, submission and reception of information, control of knowledge and skills, creative activity;

- creation of training and test programs, which can then be supplemented and improved by the students themselves.

In this article, we present the introduction of multimedia technologies in foreign languages teaching. Here is a brief description of multimedia products that we use in our teaching process (Table 1).

Here we may emphasize the following advantages of multimedia products:

- teaching goes faster and the knowledge acquisition is deeper, if a student takes a great interest in the subject;

- learning the ways of finding correct answers is more important for a student than just learning the answers themselves. That is, learning is more effective if the forms of the acquisition of knowledge and skills are such that can easily be transferred to real life conditions (which they are designed for).

- teaching goes faster if students "learn the result" of each of their answers immediately. If the answer is correct, then the students should immediately receive confirmation of that they did well, if not, they learn about it quickly as well. Even a little delay in getting the results dramatically slows the learning process down. Oftentimes our students have to wait long for the results of their tasks in traditional learning;

- being aware of the results of tasks stimulates the completion of upcoming tasks. The difficulties that students have to overcome should appear before them one by one. Moreover, the successful solution of these problems has a positive influence on motivating and activating students to learn;

- teaching goes faster if the subject programme is organized according to the principle of sequential complexity of educational material. The difficulty level of educational material is rising on a daily basis. This will continue until the desired degree of proficiency and competency is reached (Kobysia, Zarichanska, Bobliienko, 2017).

Nowadays, a paradigm shift leads to facilitation learners to become creative and communicative learners, accommodated to radical autonomy in the perspective (Bojare, Ignatjeva, 2014). The use of new tools has significantly transformed the traditional scheme of organization of the process of training, ensuring the development and implementation in practice of the variable structure of the educational process of higher education with components that allow automating many processes.

In addition, we would like to list the new technology tools that we use in our teaching process, they are:

- Speech Tools for Teachers: Announcify, Chrome Speak, DSpeech, FoxVox, PowerTalk;

- Digital Storytelling Tools: Animoto, Capzles, Cartoonist, PicLits, Pixton;

- Podcast Tools: Audacity, Easypodcast, PodOmatic, SoundCloud, VozMe;

- Survey, Polls, and Quizzes Tools: addpoll, Google Forms, Pollhost, Wufoo;

- Exercise and testing Tools: Kahoot, Socrative, Hot Potatoes;

- Online teaching platforms: Padlet, Blog, Nicenet, Canvas. 
Multimedia products and their brief description

Table 1

\begin{tabular}{|c|c|c|}
\hline № & $\begin{array}{l}\text { Multimedia } \\
\text { products }\end{array}$ & Description \\
\hline 1. & $\begin{array}{l}\text { ctronic } \\
\text { tbook, } \\
\text { ltimedia } \\
\text { ching } \\
\text { terials of }\end{array}$ & $\begin{array}{l}\text { A software tool designed to facilitate an active understanding and memorization using } \\
\text { the computer in learning process involving aural and emotional memory. It is not only } \\
\text { text information as such, but the whole technology of information delivery to the } \\
\text { consumer, namely: multimedia components; interactive elements; controls; powerful } \\
\text { search engine; hypertext link system; additional service capabilities (bookmarks, notes, } \\
\text { filing); opportunity for comfortable reading; synchronous listening and a host of other } \\
\text { things (Popov, Cuksina, Mozerova, 2001). } \\
\text { Electronic textbook, multimedia teaching materials of disciplines as software for } \\
\text { educational purposes can be represented as a system consisting of two subsystems: } \\
\text { information (substantial part) and software (software). }\end{array}$ \\
\hline 2. & $\begin{array}{l}\text { Multimedia } \\
\text { encyclopaedia, } \\
\text { multimedia } \\
\text { lectures }\end{array}$ & $\begin{array}{l}\text { The modern educational tool that combines the advantages of different multimedia } \\
\text { technologies facilitates the perception of even the heaviest educational material. Unlike } \\
\text { traditional encyclopaedia or lectures, multimedia encyclopaedia and lectures can contain } \\
\text { not only text and graphics, but also video and audio recordings, three-dimensional } \\
\text { diagrams, drawings and much more (Thamarana, 2015). }\end{array}$ \\
\hline 3. & $\begin{array}{l}\text { c } \\
\text { aids }\end{array}$ & $\begin{array}{l}\text { Visualized material, revealing the action or process necessary for a teacher to explain } \\
\text { students the new teaching material; animated historical and geographical maps, } \\
\text { electronic laboratory works (Young, Bush, 2004). }\end{array}$ \\
\hline 4. & $\begin{array}{l}\text { Film } \\
\text { even }\end{array}$ & $\begin{array}{l}\text { A film about important events. Video congratulation, corporate celebration, anniversary, } \\
\text { assigning categories, titles, awards, association or expansion, launching of a new product } \\
\text { or production resources, opening new sites, (Thamarana, 2016). }\end{array}$ \\
\hline 5. & $\begin{array}{l}\text { Presentation } \\
\text { film }\end{array}$ & $\begin{array}{l}\text { A film about the activity area of educational institutions, companies, offering the } \\
\text { products of exceptional quality, service, promotions, discounts, classic and original } \\
\text { forms of services, guarantees and other features. }\end{array}$ \\
\hline 6. & $\begin{array}{l}\text { Representative } \\
\text { films }\end{array}$ & $\begin{array}{l}\text { The history of educational institutions, businesses, the main activities, a description of } \\
\text { resources and processes, achievements, prospects, staff, goods, services, partners, } \\
\text { covered market segments. }\end{array}$ \\
\hline 7. & $\begin{array}{l}\text { Video } \\
\text { showcase }\end{array}$ & $\begin{array}{l}\text { Video sequence to show in the shopping centre or showroom. Video showcase is } \\
\text { successfully used in combination with other videos (video clips, movies) (Motteram, } \\
\text { 2013). }\end{array}$ \\
\hline 8. & $\begin{array}{l}\text { Video } \\
\text { catalogue }\end{array}$ & $\begin{array}{l}\text { Video catalogue of products and services of a company provides information on the } \\
\text { competitive advantages of quantitative and qualitative characteristics of each item. } \\
\text { Efficiency can be improved by combining the video catalogue with other videos. }\end{array}$ \\
\hline 9. & $\begin{array}{l}\text { Educational } \\
\text { video film }\end{array}$ & $\begin{array}{l}\text { Didactic videos, which a teacher can use in the classroom to explain new educational } \\
\text { material or to enhance students' learning. }\end{array}$ \\
\hline 10. & $\begin{array}{l}\text { Digitalization } \\
\text { of books }\end{array}$ & Conversion of paper sources into electronic (digital) type (Kennedy, Soifer, 2013). \\
\hline 11. & $\begin{array}{l}\text { Electronic } \\
\text { library }\end{array}$ & $\begin{array}{l}\text { The information system that allows safe and effective use of various collections of } \\
\text { electronic documents (text, image, sound, video), localized in the system, and } \\
\text { inaccessible communicational networks as well (Healey et al., 2018). }\end{array}$ \\
\hline
\end{tabular}

The use of various technologies allows implementing a differentiated approach to students by creating conditions for their independent work. The use of methodically well-constructed online materials helps to replace the means of paper visibility, frees the teacher from writing on the board, allows you to trace the material of the lesson in dynamics.

The great advantage of using technologies in comparison with traditional method means of visualization is the convenience of their storage, distribution with the ability to copy and edit. Colourful on-screen training material increases the interest and motivation of students to learn. 
According to the method of using technology in teaching foreign languages, three models of classes were implemented:

- in demo mode (one computer on the teacher's Desk + projector);

- in the individual mode (occupation in a computer class without access to the Internet);

- in individual remote mode (class in the computer room with Internet access).

To obtain relevant information, it is necessary to develop students' skills of searching for it in a constantly updated resource - the Internet. To do this, students are offered our catalogues of public sites and various online tools.

\section{Conclusions}

In recent years, new technologies have had a significant impact on the improvement of the education system and have been an important focus of the restructuring of both general and higher education. The main educational value of information technologies is that they allow creating a multisensory interactive learning environment with almost unlimited potential opportunities, which appear in the teaching and learning environment. Information technology allows not only to saturate teaching with a large amount of knowledge, but also to develop the intellectual and creative abilities of students, their ability to acquire new knowledge, as well as to work with various sources of information. Using the multimedia technologies, such as: Padlet, Canvas, Socrative, Kahoot, Hot Potatoes, Google Forms, PowerTalk for teaching foreign languages helps to increase motivation to study a particular discipline, deeper assimilation of the material, the development of skills of search, analysis and structuring of information and, ultimately, the formation of general cultural and professional competencies defined in modern state educational institutions of higher education. The materials of this article may be of use for teachers engaged in the training of specialists in the field of foreign languages, as well as students of higher educational institutions. In conclusion, this article was designed for teachers who mainly adhere to traditional and outdated methods, whereas they are virtually not sophisticated in using modern devices, applications and sources in teaching.

\section{Bibliography}

1. Artykbayeva E.V. (2014), Theory and Technology of E-Learning in Secondary School. Synopsis of a Thesis, Almaty: World Scientific Publishing.

2. Bojāre I., Ignatjeva S. (2014). Autonomous English Acquisition in Blended e-studies for Adults for Sustainable Development: Quantitative research. In V. Dislere (Ed.), The Proceedings of the International Scientific Conference Rural Environment. Education. Personality (REEP), 7. Jelgava: LLU, 42-49. Retrieved from https://llufb.llu.lv/conference/REEP/2014/Latvia-UnivAgricult-REEP-2014proceedings-42-49.pdf

3. Bruce B.C., Levin J.A. (2003). Roles for new technologies in language arts: Inquiry, communication, construction, and expression. In J. Flood, D. Lapp, J.R. Squire, J.R. Jenson (Eds.). The handbook for research on teaching the language arts ( $2^{\text {nd }}$ ed.), 649-657. NY: Macmillan. https://jgregorymcverry.com/readings/Bruce, Levin - 2003 - Roles for new technologies in language arts Inquiry, communication, construction, and expression.pdf

4. Chirwa M. (2018). Access and use of internet in teaching and learning at two selected teachers' colleges in Tanzania. International Journal of Education and Development using Information and Communication Technology (IJEDICT), 14(2), 4-16. Retrieved from

https://www.learntechlib.org/d/184687

5. Frigaard A. (2002). Does the computer lab improve student performance on vocabulary, grammar, and listening comprehension? ERIC Document Reproduction Service No. ED476749 Retrieved from https://eric.ed.gov/?id=ED476749

6. Gilakjani A.P. (2017). A Review of the Literature on the Integration of Technology into the Learning and Teaching of English Language Skills. International Journal of English Linguistics, 7(5), 95-106.

7. Gilakjani A.P., Lai-Mei L. (2012). EFL Teachers' attitudes toward using computer technology in English language teaching. Theory and Practice in Language Studies, 2(3), 630-636. doi: 10.4304/tpls.2.3.630-636 
8. Healey D., Hegelheimer V., Hubbard P., Iannou-Georgiou S., Ware P. Kessler G. (2018). TESOL Technology Standards Framework. Virginia: Teachers of English to Speakers of Other Language, Inc.

9. Kennedy S., Soifer D. (2013). Technology-Driven Innovations for Teaching English Learners. VA: Lexington Institute. Retrieved from https://www.lexingtoninstitute.org/wpcontent/uploads/2013/11/TechnologyInnovations.pdf

10. Kenzhebayev G.K., Dalayeva T.T. (2014). E-learning in the system of the pedagogical education in Kazakhstan. Procedia - Social and Behavioral Sciences, 152, 179-183. doi: 10.1016/j.sbspro.2014.09.177

11. Kobysia V.M., Zarichanska N.V., Bobliienko O.P. (2017). Creating and using electronic textbooks for language learning. Information Technologies and Learning Tools, 61(5), 15-23. doi: 10.33407/itlt.v61i5 (in Ukrainian)

12. Kunanbayeva S.S. (2000). Methodical preparation of students in the conditions of informatisation of the theory and methods of foreign language teaching. Almaty: World Scientific Publishing

13. Lam Y., Lawrence G. (2002). Teacher-student role redefinition during a computer-based second language project: Are computers catalysts for empowering change? Computer Assisted Language Learning, 15(3), 295-315. doi: 10.1076/call.15.3.295.8185

14. Motteram G. (2013). Introduction. In G. Motteram (Ed.), Innovations in Learning Technologies for English Language Teaching. London: British Council, 5-13. Retrieved from

https://www.teachingenglish.org.uk/sites/teacheng/files/C607\%20Information\%20and\%20Communica tion_WEB\%20only_final.pdf

15. Nurgalieva G.K. (2002). Pedagogical technologies of informatisation of education. Almaty: World Scientific Publishing.

16. Nurmukhanova D., Sagyndykova Zh., Līce I., Pāvulēns J. (2014). Competency - based approach to teaching foreign languages in Kazakhstan. In V. Dislere (Ed.), The Proceedings of the International Scientific Conference Rural Environment. Education. Personality (REEP), 7. Jelgava: LLU, 116-122. Retrieved from https://lufb.llu.lv/conference/REEP/2014/Latvia-Univ-Agricult-REEP2014proceedings-116-122.pdf

17. Popov N.S., Cuksina L.N., Mozerova L.A. (2001). Novije informacionie tehnologii obucenija inostranim yazikam [New information technologies for teaching foreign languages]. Materials of international scientific conference Problemi i perspektivi integracii visshej skoli Rosii v mirovuju sistemu obrazovanija i nauki [Problems and prospects of integration of higher education of Russia in the global system of education and science], 2. Voronezh, 138-140. (in Russian)

18. Rogova G.V., Rabinovich F.M., Sakharova T.E. (1991). Metodika obucheniya inostrannym yazykam $v$ sredney shkole. [Methods of teaching foreign languages in secondary school]: Prosvescheniye (in Russian).

19. Shyamlee S.D., Phil M. (2012). Use of technology in English language teaching and learning: An analysis. In International Conference on Language, Medias and Culture IPEDR, 33. Singapore: IACSIT Press, 150-156. Retrieved from http://www.ipedr.com/vol33/030-ICLMC2012-L10042.pdf

20. Thamarana S. (2015). Role of Multimedia Resources in Teaching and Learning of English Language. In G.R.S. Reddy, M. Teaching (Eds.), English Language and Literature Challenges and Solution English Language Teachers' Association of India (ELTAI), Tirupati chapter, 187-192. Retrieved from https://www.researchgate.net/publication/283214562_Role_of_Multimedia_Resources_in_Teac hing_and_Learning_of_English_Language

21. Thamarana S. (2016). Use of Multimedia technologies in English language learning: A Study. International Journal of English Language Teaching (IJELT), 4(8), 15-30, Retrieved from http://www.eajournals.org/wp-content/uploads/Use-of-Multimedia-technologies-in-Englishlanguage-learning-A-Study.pdf

22. Timuçin M. (2006). Implementing CALL in the EFL context. ELT Journal, 60(3), 262-271. doi: 10.1093/elt/cc1006

23. Young C.A., Bush J. (2004). Teaching the English Language Arts with Technology: A Critical Approach and Pedagogical Framework. Contemporary Issues in Technology and Teacher Education, 4(1) 1-22. Retrieved from https://citejournal.s3.amazonaws.com/wpcontent/uploads/2016/04/v4i1 languagearts1.pdf 